\title{
A sarcoma synoviale kezelési lehetőségei
}

\author{
Deme Dániel dr. ${ }^{1}$. Telekes András dr. ${ }^{1,2}$ \\ ${ }^{1}$ Szent Lázár Megyei Kórház, Onkológia, Salgótarján \\ ${ }^{2}$ Bajcsy-Zsilinszky Kórház, Onkológia, Budapest
}

\begin{abstract}
A sarcoma synoviale a lágyrész-sarcomák 5-10\%-ában, az összes malignus daganatok 0,05-0,1\%-ában fordul elő. Főként a végtagokon keletkezik, azonban bárhol kialakulhat. A betegek 50\%-ában 3-5 éven belül metasztázisok jelennek meg (tüdő, nyirokcsomó, csont), sőt akár 20 év elteltével is számítani lehet a sarcoma synoviale kiújulására. Az 5 éves teljes túlélés lokalizált betegség esetén 76\%, metasztatikus esetben $10 \%$. Az életkor, daganatméret, szövettani altípus és a radioterápia megtörténte befolyásolja a prognózist. Az adjuváns kemoterápia szerepe nem bizonyított. Számos klinikai vizsgálat van folyamatban a lokálisan előrehaladott, relaptálódott/refrakter és metasztatikus sarcoma synoviale kezelésére. A sarcoma synoviale biológiai viselkedésének jobb megértésével a célzott kezelés és a konvencionális terápia kombinációja válhat a jövő útjává. Orv. Hetil., 2015, 156(22), 875-880.
\end{abstract}

Kulcsszavak: sarcoma synoviale, kemoterápia, radioterápia, célzott kezelés

\section{Therapeutic options for synovial sarcoma}

Synovial sarcomas account for approximately 5 to $10 \%$ of soft tissue sarcomas and 0.05 to $0.1 \%$ of all malignant neoplasms. They predominantly affect the extremities but can occur in any part of the body. More than $50 \%$ of the patients are expected to develop metastatic disease within 3-5 years. In some patients disease recurrence may develop after 20 years. The 5-year overall survival rate is $10 \%$ for patients with metastatic disease and $76 \%$ for patients with localized one. Age, tumour size, histological subtype, and adjuvant radiotherapy influence prognosis. The role of adjuvant chemotherapy has not been proven yet. There are several ongoing clinical trials to determine the efficacy of active agents used for therapy of locally advanced, relapsed/refractory or metastatic disease. Better understanding of the biological behaviour of synovial sarcomas would provide the future way for the targeted therapy in combination with conventional treatments.

Keywords: synovial sarcoma, chemotherapy, radiotherapy, targeted therapy

Deme, D., Telekes, A. [Therapeutic options for synovial sarcoma]. Orv. Hetil., 2015, 156(22), 875-880.

(Beérkezett: 2015. március 14.; elfogadva: 2015. április 16.)

\begin{abstract}
Rövidítések
CCNDl = ciklin Dl; CR = komplett remisszió; DRFS = távoli kiújulásmentes túlélés; EFS = eseménymentes (gyógyszertoxicitás, -intolerancia, egyéb) túlélés; EpSSG = European Pediatric Soft Tissue Sarcoma Group; HDAC = hiszton-deacetiláz; IGF-1R = inzulinszerû növekedési faktor receptor-1; KT = kemoterápia; LRFS = lokális kiújulásmentes túlélés; $\mathrm{MD}=$ metasztatikus betegség; MFS = áttétmentes túlélés; OS = teljes túlélés; $\mathrm{PD}=$ progresszív betegség; PFS = progressziómentes túlélés; $\mathrm{PR}=$ parciális remisszió; $\mathrm{RT}$ = radioterápia; $\mathrm{SD}=$ stabil betegség; SEER = Surveillance, Epidemiology, and End Results; $S S$ = sarcoma synoviale
\end{abstract}

A sarcoma synoviale (SS) a ritka malignitások közé tartozik. A malignus daganatok 0,05-0,1\%-át és a lágyrészsarcomák 5-10\%-át alkotja $[1,2]$. Az SS leggyakrabban a serdülőkorúak és fiatal felnőttek 15-40 éves korosztályát érinti, azonban elófordulhat 10 éven aluli gyermekekben, sőt újszülöttekben is [3].

\section{Prognosztikai faktorok}

Több munkacsoport vizsgálta az SS-ben szenvedő páciensek túlélését befolyásoló prognosztikai faktorokat, amelyek közül az $5 \mathrm{~cm}$ vagy annál kisebb daganatméret korrelált a hosszabb túléléssel $[4,5,6,7,8,9,10,11]$. Wushou és Miao 26 vizsgálat $(\mathrm{n}=93)$ metaanalízisében tekintették át a fej-nyak régióban elhelyezkedő SS prognosztikai faktorait. Azt találták, hogy az $5 \mathrm{~cm}$ vagy annál kisebb méret esetén szignifikánsan hosszabb az OS [12]. Az SS prognosztikai faktorait az 1. táblázat tartalmazza. 
1. táblázat |Az SS pozitív prognosztikai faktorai

\begin{tabular}{|c|c|c|c|c|c|c|c|c|c|c|}
\hline & $\mathrm{n}$ & $\begin{array}{l}\text { Méret } \\
\leq 5 \mathrm{~cm}\end{array}$ & $\begin{array}{c}\text { Grade } \\
<\text { III }\end{array}$ & $\begin{array}{l}\text { Stage } \\
<\text { III }\end{array}$ & $\begin{array}{c}\text { Csökkent } \\
\text { nekrózisarány }\end{array}$ & $\begin{array}{c}\text { Csökkent } \\
\text { mitotikus } \\
\text { aktivitás }\end{array}$ & $\begin{array}{c}\text { Ép } \\
\text { sebészi } \\
\text { szél }\end{array}$ & $\begin{array}{l}\text { Végtagi } \\
\text { lokalizáció }\end{array}$ & $\begin{array}{l}\text { Adjuváns } \\
\text { radioterápia } \\
\text { megtörténte }\end{array}$ & $\begin{array}{l}\text { Kor } \\
<35 \text { év }\end{array}$ \\
\hline $\begin{array}{l}\text { Trassard, M., } \\
\text { J. Clin. Oncol., } 2001 \text { [4] }\end{array}$ & 128 & • & & • & • & • & & & & \\
\hline $\begin{array}{l}\text { McCarville, M. B., } \\
\text { AJR, } 2002[5]\end{array}$ & 59 & • & • & & & & & $\bullet$ & & • \\
\hline $\begin{array}{l}\text { Guillou, L., } \\
\text { J. Clin. Oncol., } 2004 \text { [6] }\end{array}$ & 165 & • & $\bullet$ & $\bullet$ & $\bullet$ & $\bullet$ & & & & \\
\hline $\begin{array}{l}\text { Spurell, E. L., } \\
\text { Ann. Oncol., } 2005 \text { [7] }\end{array}$ & 104 & • & $\bullet$ & & & & $\bullet$ & & $\bullet$ & $\bullet$ \\
\hline $\begin{array}{l}\text { Palmerini, E., } \\
\text { Cancer, } 2009 \text { [8] }\end{array}$ & 250 & • & & & & & & & $\bullet$ & $\bullet$ \\
\hline $\begin{array}{l}\text { Italiano, A., } \\
\text { Ann. Oncol., } 2009 \text { [9] }\end{array}$ & 237 & & • & & & & • & & & $\bullet$ \\
\hline $\begin{array}{l}\text { Krieg, A. H., } \\
\text { Ann. Oncol., } 2010 \text { [10] }\end{array}$ & 62 & • & • & • & & & • & • & & \\
\hline $\begin{array}{l}\text { Speth, B. M., } \\
\text { J. Child. Orthop., } 2011 \text { [11] }\end{array}$ & 13 & • & & $\bullet$ & & & • & $\bullet$ & & \\
\hline
\end{tabular}

Az SS-sejtek legnagyobbrészt DNS-diploiditást mutatnak, amely az agresszív kórlefolyással korrelál. A nagyszámú genetikai változást tartalmazó $(2,8,12 \mathrm{p}, 12 \mathrm{q}$ kromoszómanyerés, 3pl4 elvesztése, SAS [sarcomaamplifikált szekvencia] -gén-nyerés) aneuploid SS esetén jelentősen csökkent a túlélés. A diploid SS-sejtek az aneuploid SS-sejtekhez képest kevesebb, azonban még mindig számos kromoszomális aberrációt mutatnak. Előbbi esetén jobb prognózisra vonatkozó eredmények láttak napvilágot [13]. Míg néhány tanulmány a SYT-SSXIhordozók esetében rosszabb MFS-t közölt a SYT-SSX2hordozókkal szemben [14], addig más vizsgálatok nem találtak különbséget a két csoport között a túlélés tekintetében $[6,10]$. A lokálisan kiújuló SS előrejelzője lehet a p53-mutáció mint prognosztikai marker [15]. PTENdeletio esetén a túlélés rosszabb [16]. A kromoszomális instabilitás prognosztikai értéke SS esetében független a kemoterápiára adott választól. Azok a mechanizmusok, amelyek SS esetében a metasztázisok kialakulásához vezetnek, a daganatos betegség lényeges patológiai folyamatait alkotják. Ezeket a jelenleg alkalmazott kemoterápiás gyógyszerek gyenge hatékonysággal képesek befolyásolni [17]. Tömegspektrometriával felfedezett szecernin-1 fehérje expressziója SS-ben jó prognosztikai markernek ígérkezik a teljes és az áttétmentes túlélés tekintetében [18]. Mivel évekkel később kiújulhat az SS, ezért több mint 10 éves utánkövetés javasolt $[10,11]$.

\section{Kezelés és kimenetel}

Az SS standard kezelése a magas malignitású lágyrészsarcoma protokollja szerint ajánlott. Ez magában foglalja a sebészi reszekciót adjuváns RT-vel vagy a nélkül és/vagy doxorubicinalapú KT-t (leggyakrabban ifoszfamid kombinációval).
A sebészi reszekció után a 2 éven belüli lokális kiújulás $68 \%$, a távoli áttétek kialakulása $59,5 \%$. Az adjuváns RT után hosszabb az LRFS, azonban az irradiáció DRFS-t és az OS-t nem befolyásolja $(\mathrm{n}=237)$ [9]. Egy másik vizsgálat szerint az adjuváns RT növeli az 5 éves LRFS-t $(80 \%)$ és PFS-t (52\%) [19]. A SEER-adatbázis szerint a perioperatív RT túlélési előnyt jelent SS-ben [20]. Egy 29 éves periódust tekintve a makroszkópos reszekciót követő adjuváns KT után nőtt az 5 éves MFS (47\% vs. $27 \%)$ a 17. életévet betöltött betegek körében $(n=215)$ [21]. Az SS túlélése 30 évre visszamenóleg javulást mutat, azonban a metasztázis aránya és az MFS nem változott jelentősen $(\mathrm{n}=104)$ [7]. Más közlemény szerint 32 év alatt sem a neoadjuváns, sem az adjuváns KT-nek nem volt jelentős hatása az OS-re, LRFS-re, sem a DRFS-re $(\mathrm{n}=237)$ [9].

Mellkasfali SS esetén nagy intenzitású fokuszált ultrahang- (HIFU-) nyaláb jó lokális kontrollt nyújthat [22]. Végtagi lokalizációban alkalmazott hyperthermiás perfúzióval adott TNF-alfa és melphalan jó terápiás választ hozhat [23]. Ritka esetben - például bifázikus típusú mediastinalis SS - komplett klinikai és patológiai remisszió is elérhető volt neoadjuváns kemoterápiával, majd sebészi reszekcióval [24]. Az EpSSG által tervezett és vezetett nem randomizált, prospektív vizsgálat 7 éves periódusa alatt 21 évnél fiatalabb SS-pácienseknél $(\mathrm{n}=138)$ három rizikócsoport (figyelembe véve a stádiumot, méretet, lokalizációt, N-státust) elkülönítése alapján határozták meg a kezelést (reszekció, ifoszfamid + doxorubicin KT, RT), majd a 3 és 5 éves EFS-t [21]. A kockázatadaptált kezelési csoportokat a 2. táblázatban mutatjuk be.

Tüdoáttétek reszekciója jó túléléssel korrelál [25]. Tüdőáttétek kialakulásakor egy esetismertetés szerint teljes tüdőbesugárzást alkalmaztak jó effektivitással [26]. 
2. táblázat | Rizikóadaptált kezelési csoportok

\begin{tabular}{llll}
\hline Rizikócsoportok & SS jellemzői & Primer terápia & További terápia \\
\hline $\begin{array}{l}\text { 1. Alacsony } \\
\text { 2. Intermedier }\end{array}$ & $\leq 5 \mathrm{~cm} 0$ reszekció & - \\
& $>5 \mathrm{~cm}$ & R0 reszekció & Adjuváns KT \\
& $\leq 5 \mathrm{~cm}$ & $\mathrm{R}$ l reszekció & Adjuváns KT és adjuváns RT \\
& $>5 \mathrm{~cm}$ & Rl reszekció & Adjuváns KT-KRT-KT \\
3. Magas & Nem reszekált, & Neoadjuváns KT, & Adjuváns KRT-KT \\
& axiális lokalizáció vagy $\mathrm{N}+$ & majd reszekció & \\
\hline
\end{tabular}

3. táblázat | A salvage kemoterápiás sémák összefoglalása

\begin{tabular}{|c|c|c|c|}
\hline Típus & Dózis & $\mathrm{N}$ & $\mathrm{RR}(\%)$ \\
\hline $\begin{array}{l}\text { Ifoszfamid } \\
+ \text { etopozid }\end{array}$ & $\begin{array}{l}3000 \mathrm{mg} / \mathrm{m}^{2} \text { iv. (4 órás infúzió) } 1-3 \text {. napokon } \\
150 \mathrm{mg} / \mathrm{m}^{2} \text { iv. ( } 1 \text { órás infúzió) } 1-3 \text {. napokon } \\
3 \text { hetente }\end{array}$ & 10 & 42 \\
\hline $\begin{array}{l}\text { Ciklofoszfamid } \\
+ \text { doxorubicin } \\
+ \text { dakarbazin }\end{array}$ & $\begin{array}{l}500 \mathrm{mg} / \mathrm{m}^{2}(30-120 \text { perces infúzió }) 1 . \text { napon } \\
60 \mathrm{mg} / \mathrm{m}^{2} \text { iv. (10-20 perces infúzió) } 1 . \text { napon } \\
250 \mathrm{mg} / \mathrm{m}^{2}(15-30 \text { perces infúzió }) 1-5 . \text { napokon } \\
3 \text { hetente }\end{array}$ & 10 & 50 \\
\hline $\begin{array}{l}\text { Gemcitabin } \\
+ \text { docetaxel }\end{array}$ & $\begin{array}{l}675 \mathrm{v} .900 \mathrm{mg} / \mathrm{m}^{2} \text { iv. ( } 90 \text { perces infúzió) } 1+8 \text { napokon } \\
75 \mathrm{v} .100 \mathrm{mg} / \mathrm{m}^{2} \text { iv. ( } 1 \text { órás infúzió) } 8 \text {. napon } \\
3 \text { hetente }\end{array}$ & 13 & 53,9 \\
\hline
\end{tabular}

Az NCT02181829 klinikai vizsgálat a teljes tüdő intenzitásmodulált radioterápia hatását határozza meg.

Palliatív kemoterápiával 42-46\%-os parciális remiszszió érhető el $(n=12)$ [20]. A salvage kemoterápiás sémák között sem válaszarányban, sem túlélésben nincs különbség [27]. A 3. táblázatban foglaltuk össze a salvage kemoterápiás sémákat. Másodvonalbeli kemoterápiával 6 hónapra vonatkozólag 34\%-os válaszarány (CR, PR és SD) érhető el $(\mathrm{n}=50)$ [28]. Elörehaladott primer pleuralis SS-ben a standard kemoterápia termoterápiával történő kombinációja előnyös lehet [29]. Egy metasztatikus esetben ifoszfamidalapú KT-t követően PR-t értek el trabectedin alkalmazásával [30].

\section{Célzott kezelési lehetőségek}

Sejtkultúrákon és xenograftokon végzett kutatások alapján várhatóan több ígéretes terápiás lehetőség nyílik meg a jövőben. A célzott kezelési lehetőségek között említhetjük az angioneogenezis-gátlók, anti-IGF-1R útvonalat módosítók és a HDAC-gátlók csoportjait [31]. A sorafenib (B-raf, VEGFR, FLT3, Ret, c-Kit és PDGFRgátló) hepatocellularis carcinoma-sejtvonalakon a CCNDI szintjének csökkenését eredményezte [32]. Továbbá daganatellenes aktivitást mutatott monoterápiában, kiújult vagy metasztatikus angiosarcoma esetén (PFS 3,8 hónap [ $95 \%$ CI $2,8-5,5]$, OS 14,9 hónap [95\% CI 9,4- $\infty$, 3 hónapos PFS 64\%, 6 hónapos PFS 31\%, CR 2,7\%, PR 10,8\%, SD 56,75\%, PD 29,79\% [n = 37]), míg SS esetében szerényebb eredményt lehetett elérni: PFS 2,5

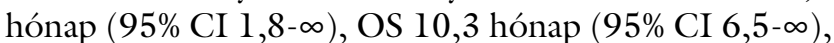
3 hónapos PFS 42\%, 6 hónapos PFS 0\%, CR 0\%, PR 0\%,
SD 50\%, PD 50\% $(\mathrm{n}=12)$ [33]. A pazopanib (VEGFR-1, $-2,-3$, PDGFR és c-Kit inhibitor) -kezeléssel előrehaladott lágyrész-sarcomában a 2 éves PFS 3,5\% [34]. A pazopanib hatását vizsgálják gemcitabin kombinációval, vagy $\mathrm{RT}+/-\mathrm{KT}$ kombinációval és neoadjuvánsan $\mathrm{KT}$ előtt. A sejtosztódást szabályozó extra- és intracelluláris fehérjék blokkolása útján ható biológiai szerekkel klinikai vizsgálatok folynak. A kizárólagosan sejtmagban elhelyezkedő IGF-1R egyszerúen vizsgálható biomarkere a sarcomáknak, amelynek célzott blokkolása (cixutumumab) metasztatikus vagy előrehaladott sarcomában hosszabb PFS-t és OS-t eredményez [35]. Fázis 2 vizsgálat során gyenge hatást mutatott, azonban a páciensek 15\%-ában SD alakult ki [36]. Egy másik antitesttel (RG1507) végzett vizsgálat során a kezelés jól tolerálható volt a válaszarány és az OS növekedése mellett [37]. In vitro és állatmodelleken végzett kísérletek alapján a hisztondeacetilációt, így az SS-sejtek osztódását gátolta az FK228 inhibitor [38]. A HDAC-gátló panobinostat fázis 2 vizsgálatban rosszul tolerált szernek bizonyult, nem szelektált populációban gyenge terápiás választ mutatott, azonban néhány beteg esetében SD alakult ki [39]. Egy fázis 2 vizsgálat az imatinibkezeléssel 13,63\%-os válaszarányt ért el $(\mathrm{n}=22)$ [40]. E hatóanyaggal végzett másik vizsgálat során CR 0\%, PR 6,3\%, SD 18,8\%, a PD 68,8\% és a progresszióig eltelt idő 1,1 hónap $(95 \%$ CI 1,0-4,1) volt $(\mathrm{n}=16)$ [41]. Liposzomális doxorubicin és temsirolimus kombináció biztonságosan adható már kemoterápiával előkezelt sarcoma esetén [42]. A 4. táblázat mutatja a molekuláris célpontokra ható szereket és a klinikai vizsgálatokat. 
4. táblázat | Az SS célzott kezelésében vizsgált hatóanyagok összefoglalása

\begin{tabular}{|c|c|c|c|c|c|c|c|}
\hline Target & Célzott terápia & Klinikai vizsgálat & & & & Várható befejezés & $\begin{array}{l}\text { Tervezett } \\
\text { betegszám }\end{array}$ \\
\hline B-raf, VEGFR & Sorafenib\$ & $\begin{array}{l}\text { + dakarbazin } \\
\text { Fázis } 2\end{array}$ & NCT00837148 & B\# & $\mathrm{L} / \mathrm{M}$ & & 37 \\
\hline Kinázgátló & Regorafenib\$ & Fázis 2 & NCT01900743 & $\mathrm{T}$ & $\mathrm{L} / \mathrm{M}$ & 2016. április & 192 \\
\hline \multirow{4}{*}{ IGFR-1 } & \multirow{3}{*}{ Cixutumumab } & $\begin{array}{l}\text { Monoterápia } \\
\text { Fázis } 2\end{array}$ & NCT00668148 & B\# & $\mathrm{L} / \mathrm{M}$ & & 185 \\
\hline & & $\begin{array}{l}\text { Monoterápia } \\
\text { Fázis } 2\end{array}$ & NCT00831844 & B\# & $\mathrm{K}$ & & 140 \\
\hline & & $\begin{array}{l}\text { + doxorubicin } \\
\text { Fázis } 1 / 2\end{array}$ & NCT00720174 & $\mathrm{F}$ & $\mathrm{L} / \mathrm{M}$ & Nem ismert & 60 \\
\hline & RG1507 & $\begin{array}{l}\text { Monoterápia } \\
\text { Fázis } 2\end{array}$ & NCT00642941 & B\# & $\mathrm{L} / \mathrm{M}$ & & 191 \\
\hline \multirow{3}{*}{ PDGFR } & \multirow{3}{*}{ Pazopanib\$ } & $\begin{array}{l}\text { Monoterápia } \\
\text { Fázis } 2\end{array}$ & NCT00297258 & $\mathrm{B}$ & $\mathrm{L}$ & & 148 \\
\hline & & $\begin{array}{l}\text { + gemcitabin } \\
\text { Fázis } 2\end{array}$ & NCT01532687 & $\mathrm{T}$ & $\mathrm{K}$ & 2016. március & 80 \\
\hline & & $\begin{array}{l}\mathrm{RT}+/- \text { ifoszfamid, doxorubicin } \\
\text { Fázis } 2 / 3\end{array}$ & NCT02180867 & $\mathrm{T}$ & $\mathrm{L}$ & 2018. június & 340 \\
\hline \multirow{3}{*}{ HDAC } & Panobinostat & $\begin{array}{l}\text { Ifoszfamid és doxorubicin } \mathrm{KT} \\
\text { és sebészi reszekció után } \\
\text { Fázis } 2\end{array}$ & NCT01446809 & $\mathrm{T}$ & $\mathrm{N}$ & 2015. április & 21 \\
\hline & \multirow[b]{2}{*}{ Vorinostat } & $\begin{array}{l}\text { Monoterápia } \\
\text { Fázis } 2\end{array}$ & NCT01136499 & B\# & $\mathrm{L} / \mathrm{M}^{*}$ & & 50 \\
\hline & & $\begin{array}{l}\text { gemcitabin } \\
+ \text { docetaxel } \\
\text { Fázis } 1 \mathrm{~b} / 2\end{array}$ & NCT01879085 & $\mathrm{T}$ & $\mathrm{L} / \mathrm{M}$ & 2020. december & 62 \\
\hline $\begin{array}{l}\text { Protein-tirozin- } \\
\text { kináz }\end{array}$ & Imatinib\$ & $\begin{array}{l}\text { + etopozid } \\
\text { Fázis } 1 / 2\end{array}$ & NCT01294670 & $\mathrm{T}$ & $\mathrm{K}$ & 2015. február & 50 \\
\hline \multirow{4}{*}{ mTOR } & \multirow{3}{*}{ Temsirolimus $\$$} & $\begin{array}{l}\text { Monoterápia } \\
\text { Fázis } 2\end{array}$ & NCT00030667 & $\mathrm{F}$ & $\mathrm{K}$ & Nem ismert & 100 \\
\hline & & $\begin{array}{l}\text { Monoterápia } \\
\text { Fázis } 1 / 2\end{array}$ & NCT00006357 & B\# & $\mathrm{K}$ & & 72 \\
\hline & & $\begin{array}{l}\text { + liposzomális doxorubicin } \\
\text { Fázis } 1 / 2\end{array}$ & NCT00949325 & B\# & $\mathrm{L} / \mathrm{M} / \mathrm{K}$ & & 45 \\
\hline & Everolimus $\$$ & $\begin{array}{l}+ \text { cixutumumab } \\
\text { Fázis } 2\end{array}$ & NCT01614795 & $\mathrm{F}$ & $\mathrm{K}$ & Nem ismert & 45 \\
\hline FZD10 & OTSAl01 & $\begin{array}{l}+ \text { imatinib } \\
\text { Fázis } 1 / 2\end{array}$ & NCT01281865 & B\# & $\mathrm{L} / \mathrm{M} / \mathrm{K}$ & & 33 \\
\hline $\begin{array}{l}\text { Gamma- } \\
\text { szekretáz-gátló }\end{array}$ & RO4929097 & Fázis l & NCT01469975 & $\mathrm{T}$ & $\mathrm{L} / \mathrm{M} / \mathrm{K}$ & Nem ismert & 18 \\
\hline \multirow[t]{2}{*}{ Wnt } & PRI-724 & $\begin{array}{l}\text { + vismodegib } \\
\text { Fázis } 1 \mathrm{~b} / 2\end{array}$ & NCT01154452 & $\mathrm{T}$ & $\mathrm{L} / \mathrm{M}$ & 2015. április & 120 \\
\hline & LGK974 & Fázis 1 & NCT01302405 & $\mathrm{T}$ & $\mathrm{L} / \mathrm{M}$ & 2015. január & 54 \\
\hline \multirow{4}{*}{ Immunterápia } & Autológ T-ly. & Fázis 1 & NCT01351103 & $\mathrm{T}$ & $?$ & 2017. január & 80 \\
\hline & \multirow{2}{*}{$\begin{array}{l}\text { NY-ESO-1 } \\
\text { specifikus T-ly. }\end{array}$} & $\begin{array}{l}\text { + ciklofoszfamid } \\
\text { Fázis } 1\end{array}$ & NCT01477021 & B\# & $\mathrm{L} / \mathrm{M}$ & & 7 \\
\hline & & Fázis 1 & NCT01343043 & $\mathrm{T}$ & $\mathrm{L} / \mathrm{M} / \mathrm{K}$ & 2031. március & 10 \\
\hline & $\begin{array}{l}\text { Autológ dendritikus } \\
\text { sejtek elleni vakcina }\end{array}$ & $\begin{array}{l}\text { Ciklofoszfamid után } \\
\text { Fázis } 1\end{array}$ & NCT02059850 & $\mathrm{T}$ & $\mathrm{L} / \mathrm{M} / \mathrm{K}$ & 2016. június & 12 \\
\hline NY-ESO-1 & ID-LV305 & $\begin{array}{l}\text { Decitabin (demetiláció után) } \\
\text { Fázis } 1\end{array}$ & NCT01241162 & $\mathrm{T}$ & A & 2015. december & 15 \\
\hline TORCl $/ 2$ & MLN0128 & Fázis 1 & NCT02122861 & $\mathrm{T}$ & $\mathrm{L} / \mathrm{M}$ & 2016. december & 36 \\
\hline Anti-PDl & Pembrolizumab & Fázis 1 & NCT01058707 & $\mathrm{T}$ & $\mathrm{L} / \mathrm{M}$ & 2015. november & 190 \\
\hline
\end{tabular}

A = adjuváns; $\mathrm{B}$ = befejezett; $\mathrm{F}$ = folyamatban; HDAC = hiszton-deacetiláz; $\mathrm{I}=$ induló vizsgálat; IGFR-1 = inzulinszerű növekedési faktor receptor- $1 ; \mathrm{K}=$ kiújult/refrakter folyamat; $\mathrm{L}=$ lokális folyamat; $\mathrm{M}=$ áttétes folyamat; $\mathrm{mTOR}=$ mammalian target of rapamycin; $\mathrm{N}=$ neoadjuváns; PDGFR = vérlemezke-eredetű növekedési faktor receptor; $\mathrm{T}=$ toborzás; VEGFR = vascularis endothelialis növekedési faktor receptor; \# = nincs publikáció; * = másodvonalbeli kezelés; $\$$ = Magyarországon elérhető. 


\section{Kísérleti szerek}

Az SS-sejtvonalakon végzett vizsgálatok alapján a RASSFlA fokozott metilációja demetilálószerrel (5-aza-20'-deoxicitidin) visszaszorítható, és az SS-sejtek proliferációja gátolható [43]. A lizinspecifikus demetiláz-1 gátlásával az SS-sejtvonalakon növekedésgátlást lehetett elérni [44].

In vitro kísérletek azt mutatták, hogy a flawokawain $\mathrm{B}$ (új chalcone a kavakivonatból) potenciálisan gátolja az SS-sejtvonalat és apoptózist indukál [45]. Az epigallocatechin-3-gallate hatékony sejtnövekedést gátló szer SSsejtvonalakon [46]. Xenograftmodellen a kis interferáló RNS (siRNS) az SS18-SSX expressziójának downregulációját eredményezi, így az SS-sejtek növekedése gátolható [47]. In vitro és in vivo körülmények között szimultán alkalmazott VEGF-gátló és CXCL12/CXCR4 kombináció hatékonyan gátolta a daganatsejtek proliferációját [48]. A Wnt-I-catenin útvonal deregulációja új terápiás célpont lehet [49]. Tumorasszociált antigének (NY-ESO-1, MAGEA4, PRAME, Survivin, SSX) elleni citotoxikus T-lymphocytákkal fázis 1 vizsgálat hamarosan indul (NCT02239861).

\section{Következtetések}

Az SS kezelésében a konvencionális terápiás eljárásokkal további lényeges javulás az OS, LRFS és a DRFS tekintetében nem várható. Új távlatot nyithat a célzott kezelés, amelyet kombinációban együtt adva az alkalmazott konvencionális modalitásokkal, betegeink életkilátásai javíthatóak.

Anyagi támogatás: A közlemény megírása anyagi támogatásban nem részesült.

Szerzôi munkamegosztás: D. D.: Az irodalmi anyag feldolgozása, a közlemény szövegének megszerkesztése és gondozása. T. A.: Az áttekintő közlemény alapgondolatának megfogalmazása. Részvétel a feldolgozandó közlemények kiválasztásában. A korábbi kéziratváltozatok áttekintése. A cikk végleges változatát mindkét szerző elolvasta és jóváhagyta.

Érdekeltségek: A szerzőknek nincsenek érdekeltségeik.

\section{Irodalom}

[1] Pack, G. T., Ariel, I. M.: Synovial sarcoma (malignant synovioma); a report of 60 cases. Surgery, 1950, 28(6), 1047-1084.

[2] Singer, S., Demetri, G. D., Baldini, E. H., et al.: Management of soft-tissue sarcomas: an overview and update. Lancet Oncol., $2000,1,75-85$.

[3] Weiss, S. W., Goldblum, J. R., Folpe, A. R.: Einzinger and Weiss's Soft Tissue Tumors. 4th edition. Mosby, Inc., Chicago, 2001.

[4] Trassard, M., Le Doussal, V., Hacène, K., et al.: Prognostic factors in localized primary synovial sarcoma: a multicenter study of 128 adult patients. J. Clin. Oncol., 2001, 19(2), 525-534.
[5] McCarville, M. B., Spunt, S. L., Skapek, S. X., et al.: Synovial sarcoma in pediatric patients. AJR, Am. J. Roentgenol., 2002, 179(3), 797-801.

[6] Guillou, L., Benhattar, J., Bonichon, F., et al.: Histologic grade, but not SYT-SSX fusion type, is an important prognostic factor in patients with synovial sarcoma: a multicenter, retrospective analysis. J. Clin. Oncol., 2004, 22(20), 4040-4050.

[7] Spurell, E. L., Fisher, C., Thomas, J. M., et al.: Prognostic factors in advanced synovial sarcoma: an analysis of 104 patients treated at the Royal Marsden Hospital. Ann. Oncol., 2005, 16(3), 437444.

[8] Palmerini, E., Staals, E. L., Alberghini, M., et al.: Synovial sarcoma: retrospective analysis of 250 patients treated at a single institution. Cancer, 2009, 115(13), 2988-2998.

[9] Italiano, A., Penel, N., Robin, Y. M., et al.: Neo/adjuvant chemotherapy does not improve outcome in resected primary synovial sarcoma: a study of the French Sarcoma Group. Ann. Oncol., $2009,20(3), 425-430$.

[10] Krieg, A. H., Hefti, F., Speth, B. M., et al.: Synovial sarcomas usually metastasize after $>5$ years: a multicenter retrospective analysis with minimum follow-up of 10 years for survivors. Ann. Oncol., 2011, 22(2), 458-467. [Epub 2010 Aug 17]

[11] Speth, B. M., Krieg, A. H., Kaelin, A., et al.: Synovial sarcoma in patients under 20 years of age: a multicenter study with a minimum follow-up of 10 years. J. Child. Orthop., 2011, 5(5), 335342.

[12] Wushou, A., Miao, X. C.: Tumor size predicts prognosis of head and neck synovial cell sarcoma. Oncol. Lett., 2015, $9(1), 381-$ 386.

[13] Balogh, Z., Szemlaky, Z., Szendroi, M., et al.: Correlation between DNA ploidy, metaphase high-resolution comparative genomic hybridization results and clinical outcome of synovial sarcoma. Diagn. Pathol., 2011, 6, 107.

[14] Ladanyi, M., Antonescu, C. R., Leung, D. H., et al.: Impact of SYT-SSX fusion type on the clinical behavior of synovial sarcoma: a multi-institutional retrospective study of 243 patients. Cancer Res., 2002, 62(1), 135-140.

[15] Papanastassiou, I., Ioannou, M., Papagelopoulos, P. J., et al.: P53 expression as a prognostic marker in giant cell tumor of bone: a pilot study. Orthopedics, 2010, 33(5). doi: 10.3928/0147744720100329-15.

[16] Teng, H. W., Wang, H. W., Chen, W. M., et al.: Prevalence and prognostic influence of genomic changes of EGFR pathway markers in synovial sarcoma. J. Surg. Oncol., 2011, 103(8), 773781.

[17] Chakiba, C., Lagarde, P., Pissaloux, D., et al.: Response to chemotherapy is not related to chromosome instability in synovial sarcoma. Ann. Oncol., 2014, 25(11), 2267-2271.

[18] Suehara, Y., Tochigi, N., Kubota, D., et al.: Secernin-1 as a novel prognostic biomarker candidate of synovial sarcoma revealed by proteomics. J. Proteomics, 2011, 74(6), 829-842.

[19] Song, S., Park, J., Kim, H. J., et al.: Effects of adjuvant radiotherapy in patients with synovial sarcoma. Am. J. Clin. Oncol., 2014 Oct 27. [Epub ahead of print]

[20] Naing, K. W., Monjazeb, A. M., Li, C. S., et al.: Perioperative radiotherapy is associated with improved survival among patients with synovial sarcoma: A SEER analysis. J. Surg. Oncol., 2015, $111(2), 158-164$.

[21] Ferrari, A., De Salvo, G. L., Brennan, B., et al.: Synovial sarcoma in children and adolescents: the European Pediatric Soft Tissue Sarcoma Study Group prospective trial (EpSSG NRSTS 2005). Ann Oncol., 2015, 26(3), 567-572.

[22] Hu, X., Cai, H., Zhou, M., et al.: New clinical application of highintensity focused ultrasound: local control of synovial sarcoma. World J. Surg. Oncol., 2013, 11, 265.

[23] Schwindenhammer, B., Podleska, L. E., Kutritz, A., et al.: The pathologic response of resected synovial sarcomas to hyperthermic isolated limb perfusion with melphalan and TNF- $\alpha$ : a com- 
parison with the whole group of resected soft tissue sarcomas. World J. Surg. Oncol., 2013, 11(1), 185.

[24] Balieiro, M. A., Lopes, A. J., Costa, B. P., et al.: The surprising outcome of a giant primary mediastinal synovial sarcoma treated with neoadjuvant chemotherapy. J. Thorac. Dis., 2013, 5(1), 94-96.

[25] Stanelle, E. J., Christison-Lagay, E. R., Wolden, S. L., et al.: Pulmonary metastasectomy in pediatric/adolescent patients with synovial sarcoma: an institutional review. J. Pediatr. Surg., 2013, $48(4), 757-763$.

[26] Gerber, N. K., Meyers, P. A., LaQuaglia, M. P., et al.: Whole-lung irradiation in the treatment of metastatic synovial sarcoma. Pediatr. Blood Cancer, 2014, 61(11), 2092-2093.

[27] Yetisyigit, T., Arpaci, E., Seber, E. S., et al.: Salvage treatment experience in advanced synovial sarcoma: a multicenter retrospective analysis of the Anatolian Society of Medical Oncology. Asian Pac. J. Cancer Prev., 2013, 14(9), 5185-5188.

[28] Minchom, A., Jones, R. L., Fisher, C., et al.: Clinical benefit of second-line palliative chemotherapy in advanced soft-tissue sarcoma. Sarcoma, 2010, 2010, Article ID 264360.

[29] Abe, K., Maebayashi, T., Shizukuishi, T., et al.: Radiological assessment following thermoradiation therapy for primary pleural synovial sarcoma: case report. Med. Oncol., 2010, 27(3), 10271030.

[30] Zanardi, E., Maruzzo, M., Montesco, M. C., et al.: Response to trabectedin in a patient with advanced synovial sarcoma with lung metastases. Anticancer Drugs, 2014, 25(10), 1227-1230.

[31] Jones, K. B., Haldar, M., Schiffman, J. D., et al.: Of mice and men: opportunities to use genetically engineered mouse models of synovial sarcoma for preclinical cancer therapeutic evaluation. Cancer Control, 2011, 18(3), 196-203.

[32] Liu, L., Cao, Y., Chen, C., et al.: Sorafenib blocks the RAF/ MEK/ERK pathway, inhibits tumor angiogenesis, and induces tumor cell apoptosis in hepatocellular carcinoma model PLC/ PRF/5. Cancer Res., 2006, 66(24), 11851-11858.

[33] Maki, R. G., D’Adamo, D. R., Keohan, M. L., et al.: Phase II study of sorafenib in patients with metastatic or recurrent sarcomas. J. Clin. Oncol., 2009, 27(19), 3133-3140.

[34] Kasper, B., Sleijfer, S., Litière, S., et al.: Long-term responders and survivors on pazopanib for advanced soft tissue sarcomas: subanalysis of two European Organisation for Research and Treatment of Cancer (EORTC) clinical trials 62043 and 62072. Ann. Oncol., 2014, 25(3), 719-724.

[35] Asmane, I., Watkin, E., Alberti, L., et al.: Insulin-like growth factor type 1 receptor (IGF-1R) exclusive nuclear staining: a predictive biomarker for IGF-1R monoclonal antibody $(\mathrm{Ab})$ therapy in sarcomas. Eur. J. Cancer, 2012, 48(16), 3027-3035.

[36] Weigel, B., Malempati, S., Reid, J. M., et al.: Phase 2 trial of cixutumumab in children, adolescents, and young adults with refractory solid tumors: a report from the Children's Oncology Group. Pediatr. Blood Cancer, 2014, 61(3), 452-456.

[37] Pappo, A. S., Patel, S. R., Crowley, J., et al.: R1507, a monoclonal antibody to the insulin-like growth factor 1 receptor, in patients with recurrent or refractory Ewing sarcoma family of tumors: results of a phase II Sarcoma Alliance for Research through Collaboration study. Clin. Oncol., 2011, 29(34), 4541-4547.
[38] Ito, T., Ouchida, M., Morimoto, Y., et al.: Significant growth suppression of synovial sarcomas by the histone deacetylase inhibitor FK228 in vitro and in vivo. Cancer Lett., 2005, 224(2), 311319.

[39] Cassier, P. A., Lefranc, A., Amela, E. Ү., et al.: A phase II trial of panobinostat in patients with advanced pretreated soft tissue sarcoma. A study from the French Sarcoma Group. Br. J. Cancer, 2013, 109(4), 909-914.

[40] Chugh, R., Wathen, J. K., Maki, R. G., et al.: Phase II multicenter trial of imatinib in 10 histologic subtypes of sarcoma using a bayesian hierarchical statistical model. J. Clin. Oncol., 2009, 27(19), 3148-3153.

[41] Heinrich, M. C., Joensuu, H., Demetri, G. D., et al.: Phase II, open-label study evaluating the activity of imatinib in treating lifethreatening malignancies known to be associated with imatinibsensitive tyrosine kinases. Clin. Cancer Res., 2008, 14(9), 27172725.

[42] Thornton, K. A., Chen, A. R., Trucco, M. M., et al.: A dose-finding study of temsirolimus and liposomal doxorubicin for patients with recurrent and refractory bone and soft tissue sarcoma. Int. J. Cancer, 2013, 133(4), 997-1005.

[43] Numoto, K., Yoshida, A., Sugibara, S., et al.: Frequent methylation of RASSFIA in synovial sarcoma and the anti-tumor effects of 5-aza-2'-deoxycytidine against synovial sarcoma cell lines. J. Cancer Res. Clin. Oncol., 2010, 136(1), 17-25.

[44] Schildhaus, H. U., Riegel, R., Hartmann, W., et al.: Lysine-specific demethylase 1 is highly expressed in solitary fibrous tumors, synovial sarcomas, rhabdomyosarcomas, desmoplastic small round cell tumors, and malignant peripheral nerve sheath tumors. Hum. Pathol., 2011, 42(11), 1667-1675.

[45] Sakai, T., Eskander, R. N., Guo, ., et al.: Flavokawain B, a kava chalcone, induces apoptosis in synovial sarcoma cell lines. Orthop. Res., 2012, 30(7), 1045-1050.

[46] Sun, Y., Wang, H., Lin, F., et al.: Inhibition of proliferation and gene expression regulation by (-)-epigallocatechin-3-gallate in human synovial sarcoma cells. Med. Oncol., 2011, 28(4), 14631468 .

[47] Takenaka, S., Naka, N., Araki, N., et al.: Downregulation of SS18-SSXI expression in synovial sarcoma by small interfering RNA enhances the focal adhesion pathway and inhibits anchorage-independent growth in vitro and tumor growth in vivo. Int. J. Oncol., 2010, 36(4), 823-831.

[48] Wakamatsu, T., Naka, N., Sasagawa, S., et al.: Deflection of vascular endothelial growth factor action by SS18-SSX and composite vascular endothelial growth factor- and chemokine (C-X-C motif) receptor 4-targeted therapy in synovial sarcoma. Cancer Sci., 2014, 105(9), 1124-1134.

[49] Nielsen, T. O., Poulin, N. M., Ladanyi, M.: Synovial sarcoma: recent discoveries as a roadmap to new avenues for therapy. Cancer Discov., 2015, 5(2), 124-134

(Deme Dániel dr., Salgótarján, Füleki út 54-56., 3100 e-mail: danieldeme_md@ymail.com) 